\title{
A Chemically Derived Milk Substitute that is Compatible with Mouse Milk for Artificial Rearing of Mouse Pups
}

\author{
Masako YAJIMA, Takahiro KANNO, and Takaji YAJIMA, \\ Food Function and Nutrition Science Institute, Division of Research and Development, \\ Meiji Dairies Corporation, 540 Naruda, Odawara, Kanagawa 250-0862, Japan
}

\begin{abstract}
The object of this study was to prepare a chemically derived milk substitute that is compatible with mouse-milk. Milk was independently collected from ICR, BALB/c, and $F V B / N$ mice, and analyzed for the protein, fat, and mineral contents to formulate a milk substitute. Thereafter, ICR mouse pups were artificially reared on the milk substitute to evaluate the rate of increase of their body weights. A gastric cannula tube was placed through the esophageal way into 8-day-old ICR pups, and the mice were fed with the milk substitute by computer-regulated infusion pumping by the pup-in-a-cup method. The analytical mean values of total protein and total fat in milk from ICR, BALB/C, and FVB/N mice were $10.23 \pm 0.49 \%$ and $21.34 \pm 1.31 \%$, respectively. The milk substitute was constituted from purified bovine casein and whey proteins, five edible oils, including MCT oil, minerals, and vitamins. After 8 days of artificial rearing with the new milk substitute, 36 of the 42 pups had survived, and the growth rate of these mice was not significantly different from that of maternally reared littermate pups. In conclusion, we have succeeded in the preparation of a chemically derived milk substitute for mice pups which is available for clarifying the roles of dietary components such as milk-bone substance during the suckling period in mice pups including those of knockout and transgenic mice.
\end{abstract}

Key words: artificial rearing, chemical milk substitute, mouse

\section{Introduction}

A practical method of artificially rearing mouse pups is desirable for neonatal nutrition and genetic studies because mice are used more commonly than rats in experiments using transgenic and knockout animals. Furthermore, antibody reagents of mice are commercially available. Recently, Beierle et al. reported artificial rearing of mice pups using gastrostomy cath- eters [2], and Hoshiba developed hand-feeding tools for mice, including a surrogate nipple with a nursing bottle [4]. They both used milk substitutes, such as that for rodents or a commercially available dog formula.

Although a chemically derived milk substitute to support rat pup growth has already been developed [5-7], no chemically derived milk substitute for rearing mice which achieves sufficient growth has been developed

(Received 9 September 2005 / Accepted 12 April 2006)

Address corresponding: M. Yajima, Food Science Institute, Division of Research and Development, Meiji Dairies Corporation, 540 Naruda, Odawara, Kanagawa 250-0862, Japan 
yet. The aim of this study was to prepare a chemically derived milk substitute for mice, and to rear mouse pups using the new milk substitute and compare them with maternally reared pups.

\section{Materials and Methods}

Meiji Dairies Corporation's Committee for Research on Experimental Animals approved the experimental protocol. Experiments were conducted in accordance with the NRC Guide for the Care and Use of Laboratory Animals (NRC, 1985).

\section{Animals}

Pregnant ICR and BALB/c mice were purchased from Japan SLC (Shizuoka, Japan), and pregnant FVB/N mice from CLEA JAPAN, Inc. (Tokyo Japan). All animals were kept individually under environmentally controlled temperature $\left(25 \pm 2^{\circ} \mathrm{C}\right)$, humidity $(50 \pm 5 \%$ relative humidity), and light (12-h light-dark cycle) conditions. They had free access to water and chow (CA-1; Japan Clea, Tokyo, Japan) and were allowed to deliver spontaneously.

\section{Analyses of the composition of mouse milk}

Four dams of each species of mouse, ICR, BALB/c, and $\mathrm{FVB} / \mathrm{N}$, were milked during 4-12 days post partum. The milking was done every other day after intra-peritoneal stimulation by injection of $0.05 \mathrm{ml}$ of $0.01 \%$ oxytocin (Peptide Institute Inc., Osaka, Japan) with pentobarbital sodium anesthetic.

The milk of each species was pooled until analysis. The total protein was measured with an automatic analyzer, Kjeltec 2300 (FOSS Japan, Tokyo). Total milk fat was measured by using lipid extraction and gravimetric methods. One milliliter of milk was diluted to $10 \mathrm{ml}$ with distilled and deionized water (DW). Then, $2 \mathrm{ml}$ of ammonium and $10 \mathrm{ml}$ of ethanol were then added and mixed. In addition, $25 \mathrm{ml}$ of diethyl ether were added to the mixture, followed by vigorous mixing, and then, $25 \mathrm{ml}$ of petroleum ether were added, followed by more vigorous mixing. After standing the mix for more than $45 \mathrm{~min}$, the diethyl ether in the upper layer was placed in a pre-dried and weighed flask. After that, the second extraction was done by adding $15 \mathrm{ml}$ of fresh diethyl ether and $15 \mathrm{ml}$ of petroleum ether. The two portions of diethyl ether extracts were mixed in the same flask and dried at $96-98^{\circ} \mathrm{C}$ for $2 \mathrm{~h}$ in a vacuum oven. The total fat was weighed after cooling in plastic desiccators. The minerals were measured by atomic absorption spectrophotometry after appropriate dilution directly after heating at $550^{\circ} \mathrm{C}$ for over $5 \mathrm{~h}$. The osmotic pressure of the milk was determined by measuring the freezing point depression (Osmostat6020, Daiichi Kagaku Co., Ltd., Kyoto, Japan). The micelle size of the milk was determined with a laser diffraction particle size analyzer (SALD-2000, Shimadzu, Kyoto, Japan).

\section{Composition and preparation of the mouse formula (MCW64)}

The protein and fat in the milk substitute were prepared to mimic the contents of those found in the three species of mice milk analyzed in this study. The formula consisted of proteins such as purified bovine casein and whey proteins. Five edible oils, including MCT oil, were added to the composition as in milk substitute for rats [5]; however, the oil contents were approximately 1.3 times higher than those used in the rat formula prepared by Kanno et al. [5]. Vitamins were added at approximately the same concentration as those used in the rat formula prepared by Auested et al. [1].

\section{Artificial rearing of ICR mice using the milk substitute for mice}

Ten mice were allowed to deliver spontaneously. At 8 days after birth, the pups were weighed and divided into 2 groups at random in order to eliminate the influence of inter-litter variation. In the first group, a litter of 10 pups was reared by one of the dams throughout the study (maternally reared: MR). In the second group, an intragastric cannula was implanted in the gastric wall through the esophageal way in each pup using Hall's method [3], and they were then artificially reared (AR) on the milk substitute. The volume of the formula which was fed to the AR pups was determined daily for comparison with the growth of the MR pups and increased from $0.6 \mathrm{ml}$ on day 8 to $1.2 \mathrm{ml}$ on day 15 . The syringe on the pump was placed in a refrigerator $\left(5^{\circ} \mathrm{C}\right)$ to prevent bacterial growth in the milk formula inside the tubes. If the cannula fell off during the artificial rearing, the mice were sacrificed. 


\section{Cannula for pups}

The artificial rearing method used in this study involved implanting a cannula in the stomach. The milk-pumping side of the cannula tube passed from the inside to the outside of the walls of the stomach and abdomen using a piano wire as a guide, and the inner gastric side of the cannula was fixed by a rim with a thin plastic disk of $3 \mathrm{~mm}$ in diameter to prevent it from coming out of the stomach wall. The cannula was made of a clear vinyl tube that was $0.2 \mathrm{~mm}$ in inner diameter and $0.5 \mathrm{~mm}$ in outer diameter (SV8, Natume Seisakusho Co., Ltd., Tokyo, Japan) and was attached to a 5-ml syringe pump connected to a polyethylene tube (PE50).

\section{Results}

Protein, fat, and mineral contents of the milk in ICR, $B A L B / c$, and $F V B / N$ mice

The concentrations of protein, fat and some minerals in the milks from ICR, BALB/c and FVB/N mice are shown in Table 1. The fat concentrations were $22.8 \%$, $21.1 \%$, and $20.2 \%$ in ICR, BALB/c and FVB/N mice, respectively, and the average value of the fat concentration was $21.3 \pm 1.3 \%$. The protein concentrations were $11.3 \%, 10.3 \%$, and $10.9 \%$, in ICR, BALB/c and $\mathrm{FVB} / \mathrm{N}$ mice, respectively, and the average value of the protein concentration was $10.8 \pm 0.5 \%$. We did not analyze the concentrations of vitamins, sugars, and fatty acids.

\section{Composition and preparation of the chemically derived milk substitute for mice pups}

The composition of the milk substitute for mice pups is listed in Table 2. The concentrations of vitamins in the mouse milk substitute were those used by Auestad et al. [1] with the exception of enriched ascorbic sodium, and the fats used were the same as those used in a rat milk substitute [3], though the concentrations were different.

Table 3 is a flow table for the preparation ( $4 \mathrm{~L})$ of the milk substitute, MCW64. The preparation procedure is similar to that for the rat milk substitute by Kanno et al. [5].

The first step was the preparation of casein mixture. Three amino acids, serine ( $1.15 \mathrm{~g})$, cystine $(0.90 \mathrm{~g})$, and tryptophan $(1.08 \mathrm{~g})$, were added to an alkaline solution $(1.35 \mathrm{~L})$ of $\mathrm{NaOH}(2.4 \mathrm{~g})$ and $\mathrm{KOH}(6.8 \mathrm{~g})$, under continuous stirring with a motor-driven stirrer (three-one motor, Heidon, Tokyo, Japan) at $60-70^{\circ} \mathrm{C}$ before the addition of casein. Then, bovine casein $(266.05 \mathrm{~g})$ was slowly dissolved in the alkaline solution. The casein solution was sterilized by boiling in a water bath for $30 \mathrm{~min}$. In the second step, calcium and

Table 1. Concentrations of milk fat, protein, and minerals in mouse milks

\begin{tabular}{cccccc}
\hline \multicolumn{2}{c}{ concentration } & \multicolumn{4}{c}{ mouse milk } \\
\cline { 3 - 6 } & & ICR & BALB/c & FVB/N & average \pm SD \\
\hline \multirow{2}{*}{ fat } & $\mathrm{g} / 100 \mathrm{ml}$ & 22.8 & 21.1 & 20.2 & $21.3 \pm 1.3$ \\
protein & $\mathrm{g} / 100 \mathrm{ml}$ & 11.3 & 10.3 & 10.9 & $10.8 \pm 0.5$ \\
$\mathrm{Fe}$ & $\mathrm{mg} / 100 \mathrm{ml}$ & 4.91 & n.t. & 1.0 & $3.0 \pm 2.8$ \\
$\mathrm{Na}$ & $\mathrm{mg} / 100 \mathrm{ml}$ & 84.23 & n.t. & 186.7 & $135.5 \pm 72.5$ \\
$\mathrm{Ca}$ & $\mathrm{mg} / 100 \mathrm{ml}$ & 360.00 & n.t. & n.t. & \\
$\mathrm{P}$ & $\mathrm{mg} / 100 \mathrm{ml}$ & 216.00 & n.t. & n.t. & \\
$\mathrm{K}$ & $\mathrm{mg} / 100 \mathrm{ml}$ & 109.00 & n.t. & n.t. \\
$\mathrm{Cl}$ & $\mathrm{mg} / 100 \mathrm{ml}$ & 147.00 & n.t. & n.t. & \\
$\mathrm{Mg}$ & $\mathrm{mg} / 100 \mathrm{ml}$ & 24.00 & n.t. & n.t. & \\
$\mathrm{Zn}$ & $\mathrm{mg} / 100 \mathrm{ml}$ & 1.12 & n.t. & n.t. & \\
$\mathrm{Cu}$ & $\mathrm{mg} / 100 \mathrm{ml}$ & 0.26 & n.t. & n.t. & \\
$\mathrm{Mn}$ & $\mathrm{mg} / 100 \mathrm{ml}$ & 0.01 & n.t. & n.t. & \\
$\mathrm{Al}$ & $\mathrm{mg} / 100 \mathrm{ml}$ & 0.03 & n.t. & n.t. & \\
\hline
\end{tabular}

Milk was obtained from ICR, FVB/N and BALB/c mice to determine the concentrations of fat, total fat, total protein, iron $(\mathrm{Fe})$, sodium $(\mathrm{Na})$, calcium $(\mathrm{Ca})$, phosphprus $(\mathrm{P})$, potassium $(\mathrm{K})$, chloride $(\mathrm{Cl})$, magnesium $(\mathrm{Mg})$, zinc $(\mathrm{Zn})$, copper $(\mathrm{Cu})$, manganase $(\mathrm{Mn})$ and aluminum ( $\mathrm{Al})$. Abbreviations used: n.t.,not tested; $\mathrm{SD}$, standard deviation. 
Table 2. Nutrient composition and physical properties of the milk substitutes for mouse and rat pups

\begin{tabular}{|c|c|c|}
\hline \multirow{2}{*}{$\begin{array}{l}\text { nutrients } \\
\text { (weight / } 100 \mathrm{ml} \text { ) }\end{array}$} & \multicolumn{2}{|c|}{ milk substitutes } \\
\hline & for mice & for rats" \\
\hline Protein $(\mathrm{g})$ & 9.40 & 9.00 \\
\hline Casein & 5.75 & 5.40 \\
\hline Whey & 3.64 & 3.60 \\
\hline \multicolumn{3}{|l|}{ Carbohydrate (g) } \\
\hline lactose & 2.40 & 2.50 \\
\hline Fat $(g)$ & 16.00 & 12.00 \\
\hline Palm oil & 4.79 & 3.60 \\
\hline Coconut oil & 3.99 & 3.00 \\
\hline Soya oil & 3.19 & 2.40 \\
\hline MCT oil & 2.39 & 1.80 \\
\hline Corn oil & 1.60 & 1.20 \\
\hline Cholesterol & 0.04 & 0.04 \\
\hline \multicolumn{3}{|l|}{ Minerals (mg) } \\
\hline Calcium & 320.00 & 315.00 \\
\hline Phosphorus & 193.00 & 207.00 \\
\hline Sodium & 96.00 & 128.00 \\
\hline Potassium & 125.00 & 122.00 \\
\hline Chloride & 110.00 & 160.00 \\
\hline Magnesium & 20.00 & 21.00 \\
\hline Zinc & 1.37 & 2.40 \\
\hline Copper & 0.41 & 0.0006 \\
\hline Fluorine & 0.029 & 0.07 \\
\hline Iodine & 0.139 & 0.14 \\
\hline Iron & 4.62 & \\
\hline Manganese & 0.02 & \\
\hline Alminium & 0.027 & \\
\hline \multicolumn{3}{|l|}{ Vitamins (mg) } \\
\hline Cyanocobalamin & 0.00119 & 0.00119 \\
\hline Biotin & 0.018 & 0.018 \\
\hline Folic acid & 0.079 & 0.079 \\
\hline Thiamin hydrochloride & 0.881 & 0.881 \\
\hline Pyridoxin hydrochloride & 1.25 & 1.25 \\
\hline Riboflavin sodium phosphate & 1.415 & 1.415 \\
\hline Calcium pantothenic acid & 2.643 & 2.643 \\
\hline p-Amino-benzoic acid & 4.404 & 4.404 \\
\hline Nicotinic acid & 4.988 & 4.988 \\
\hline Sodium ascorbate & 47.4 & 47.4 \\
\hline 4-Inositol & 49.725 & 49.725 \\
\hline Choline citrate & 0.14 & 0.14 \\
\hline Vit.E: $\alpha$-tocopherol & 2.35 & 2.346 \\
\hline Vit.K & 1.98 & 1.982 \\
\hline Vit.A (I.U.) & 42.8 & 42.8 \\
\hline Vit.D (I.U.) & 10 & 10 \\
\hline \multicolumn{3}{|l|}{ Others (mg) } \\
\hline Carnitine & 4 & 3.5 \\
\hline Picolinate & 2 & 2 \\
\hline Ethanolamine & 3.4 & 3.5 \\
\hline Taurine & 15 & 15 \\
\hline Cysteine & 22.5 & 22.5 \\
\hline Serine & 28.75 & 27.5 \\
\hline Tryptophan & 27 & 27.5 \\
\hline Energy contents $(\mathrm{Kj} / 100 \mathrm{ml}$ of milk) & $790.2 \mathrm{c}$ & 637 \\
\hline Osmolarity $\left(\mathrm{mOsm} / \mathrm{kg} \mathrm{H}_{2} \mathrm{O}\right)$ & $327^{*}$ & $343 \pm 12^{*}$ \\
\hline $\mathrm{pH}$ & $6.51^{*}$ & $6.5 \pm 0.1^{*}$ \\
\hline Size of micelles (microns) & $1.5^{*}$ & $1.1 \pm 0.1^{*}$ \\
\hline
\end{tabular}

c conversion factors in mice: $1 \mathrm{~g}$ protein $=17 \mathrm{kj}, 1 \mathrm{~g}$ carbohydrate $=16 \mathrm{kj}, 1 \mathrm{~g}$ fat $=37 \mathrm{kj} .{ }^{*}$ values (values $\pm \mathrm{SD}$ ) obtained by analysis. Inutrient composition of milk substitute for rat pups quoted from Kanno et al. [3]. 
Table 3. Preparation of formula for mouse pups

\begin{tabular}{|c|c|c|}
\hline \multicolumn{3}{|c|}{ Steps } \\
\hline process No. & reagents & weights or volume \\
\hline \multirow[t]{3}{*}{$1 \mathrm{a}$} & $\mathrm{NaOH}$ & $2.4 \mathrm{~g}$ \\
\hline & $\mathrm{KOH}$ & $6.8 \mathrm{~g}$ \\
\hline & & D.W. $1350 \mathrm{ml}$ \\
\hline \multirow[t]{3}{*}{$1 b$} & Serine & $1.15 \mathrm{~g}$ \\
\hline & Cystine & $0.90 \mathrm{~g}$ \\
\hline & Tryptophan & $1.08 \mathrm{~g}$ \\
\hline $1 \mathrm{c}$ & Casein & $266.1 \mathrm{~g}$ \\
\hline \multirow[t]{4}{*}{2} & $\mathrm{CaCl}_{2} \cdot 2 \mathrm{H}_{2} \mathrm{O}$ & $4.4 \mathrm{~g}$ \\
\hline & $\mathrm{GlyCaPO}_{4}$ & $32.0 \mathrm{~g}$ \\
\hline & $\mathrm{MgCl}_{2} \cdot 6 \mathrm{H}_{2} \mathrm{O}$ & $6.4 \mathrm{~g}$ \\
\hline & & D.W. $200 \mathrm{ml}$ \\
\hline \multirow[t]{3}{*}{3} & $\mathrm{CaCO}_{3}$ & $10 \mathrm{~g}$ \\
\hline & $\mathrm{Ca}_{3}$ Citrate $\cdot 4 \mathrm{H}_{2} \mathrm{O}$ & $4.8 \mathrm{~g}$ \\
\hline & & D.W. $100 \mathrm{ml}$ \\
\hline \multirow[t]{3}{*}{4} & $\mathrm{Na}_{2} \mathrm{HPO}_{4}$ & $3.2 \mathrm{~g}$ \\
\hline & $\mathrm{KH}_{2} \mathrm{PO}_{4}$ & $0.32 \mathrm{~g}$ \\
\hline & & D.W. $50 \mathrm{ml}$ \\
\hline \multirow[t]{2}{*}{5} & Lactose $\cdot \mathrm{H}_{2} \mathrm{O}$ & $74.05 \mathrm{~g}$ \\
\hline & & D.W. $220 \mathrm{ml}$ \\
\hline \multirow[t]{2}{*}{6} & WPI & $160 \mathrm{~g}$ \\
\hline & & D.W. $600 \mathrm{ml}$ \\
\hline \multirow[t]{3}{*}{7} & $\mathrm{FeSO}_{4} \cdot 7 \mathrm{H}_{2} \mathrm{O}$ & $0.92 \mathrm{~g}$ \\
\hline & Citrate $\cdot \mathrm{H}_{2} \mathrm{O}$ & $0.02 \mathrm{~g}$ \\
\hline & & D.W. $5 \mathrm{ml}$ \\
\hline \multirow[t]{4}{*}{8} & $\mathrm{ZnSO}_{4} \cdot 7 \mathrm{H}_{2} \mathrm{O}$ & $0.24 \mathrm{~g}$ \\
\hline & $\mathrm{CuSO}_{4} \cdot 5 \mathrm{H}_{2} \mathrm{O}$ & $0.06 \mathrm{~g}$ \\
\hline & $\mathrm{MnSO}_{4} \cdot 5 \mathrm{H}_{2} \mathrm{O}$ & $0.003 \mathrm{~g}$ \\
\hline & & D.W. $5 \mathrm{ml}$ \\
\hline \multirow[t]{3}{*}{9} & $\mathrm{NaF}$ & $0.006 \mathrm{~g}$ \\
\hline & $\mathrm{KI}$ & $0.01 \mathrm{~g}$ \\
\hline & & D.W. $5 \mathrm{ml}$ \\
\hline \multirow[t]{5}{*}{10} & Carnitine & $0.16 \mathrm{~g}$ \\
\hline & Picolinate & $0.08 \mathrm{~g}$ \\
\hline & Ethanolamine & $0.136 \mathrm{~g}$ \\
\hline & Taurine & $0.6 \mathrm{~g}$ \\
\hline & & D.W. $10 \mathrm{ml}$ \\
\hline \multirow[t]{4}{*}{11} & Na-Choline-Dihydrogencitrate & $5.6 \mathrm{~g}$ \\
\hline & & D.W. $70.0 \mathrm{ml}$ \\
\hline & $10 \mathrm{~N}-\mathrm{NaOH}$ & $1.82 \mathrm{ml}$ \\
\hline & Vitamin Mix. & $20 \mathrm{~g}$ \\
\hline \multirow[t]{9}{*}{12} & Palm oil & $191.5 \mathrm{~g}$ \\
\hline & Coconut oil & $159.6 \mathrm{~g}$ \\
\hline & Corn oil & $63.84 \mathrm{~g}$ \\
\hline & MCToil & $95.76 \mathrm{~g}$ \\
\hline & Soya oil & $127.68 \mathrm{~g}$ \\
\hline & Cholesterol & $0.0016 \mathrm{~g}$ \\
\hline & Vit.K & $0.0793 \mathrm{~g}$ \\
\hline & Vit.E & $0.0938 \mathrm{~g}$ \\
\hline & Vit A and D mixture & $0.0057 \mathrm{~g}$ \\
\hline 13 & & D.W. $[138.5] \mathrm{ml}$ \\
\hline
\end{tabular}


magnesium were added to the casein solution to obtain micelles of casein salts as follows. The salts of $\mathrm{CaCl}_{2} \cdot 2 \mathrm{H}_{2} \mathrm{O}(4.4 \mathrm{~g})$, glycerophosphoric acid calcium salt (32 g), and $\mathrm{MgCl}_{2} \cdot 6 \mathrm{H}_{2} \mathrm{O}(6.4 \mathrm{~g})$ were mixed in 200 $\mathrm{ml} \mathrm{DW}$, which was autoclaved $\left(121^{\circ} \mathrm{C}\right.$ for $\left.10 \mathrm{~min}\right)$ and then homogenized with a Polytron-like mixer (Nihonseiki Kaisha Ltd., Tokyo, Japan). After that, the mixture was slowly added to the protein solution under continuous mixing with an Ultra-Turrax (IKA Labotechnik, Germany). Then, $\mathrm{CaCO}_{3}(10.0 \mathrm{~g})$ and calcium citrate $(4.8 \mathrm{~g})$ in $100 \mathrm{ml}$ of DW were also slowly added to the protein solution after autoclaving and homogenization. A mixture of $\mathrm{Na}_{2} \mathrm{HPO}_{4}(3.2 \mathrm{~g})$ and $\mathrm{KH}_{2} \mathrm{PO}_{4}(0.32 \mathrm{~g})$ in $50 \mathrm{ml}$ of $\mathrm{DW}$, sterilized by an autoclave in advance, was added to the casein micelle suspension. Then, a lactose solution (74.5 g of lactose in $220 \mathrm{ml}$ ) was slowly added to avoid foaming. Solutions of $\mathrm{FeSO}_{4} \cdot 7 \mathrm{H}_{2} \mathrm{O}(0.92 \mathrm{~g})$ and citrate $(0.02 \mathrm{~g})$, $\mathrm{ZnSO}_{4}(0.24 \mathrm{~g}), \mathrm{CuSO}_{4}(0.06 \mathrm{~g})$, and $\mathrm{MnSO}_{4}(0.003 \mathrm{~g})$, and $\mathrm{NaF}(0.0062 \mathrm{~g})$ and $\mathrm{KI}(0.01 \mathrm{~g})$ were consecutively added to the casein micelle suspension under continuous stirring after sterilization by Millipore filtration (0.45 micrometer). Whey protein (160 g), which was sterilized by gamma-irradiation ( $30 \mathrm{kGy}$ ) in advance, was dissolved in DW $(600 \mathrm{ml})$ and then added to the casein and salt mixture after cooling to below $40^{\circ} \mathrm{C}$ under continuous stirring. A mixed solution of carnitine $(0.16 \mathrm{~g})$, picolinate $(0.08 \mathrm{~g})$, ethanolamine $(0.136$ $\mathrm{g})$, taurine $(0.6 \mathrm{~g})$, and a mixture of water-soluble vitamins (20 g) was added after Millipore filter sterilization ( 0.45 micrometer). Then, fatty vitamins and a mixture of five edible oils were added to the above mixture under continuous stirring after sterilization by boiling in a water bath for $30 \mathrm{~min}$. Finally, the total mixture was weighted up to 4,000 g by adding DW (No.13).

The milk substitute was then homogenized three times under high pressure $\left(180 \mathrm{Kg} / \mathrm{cm}^{2}\right)$ using a homogenizer (Sanwa Machine Co., Ltd., Numazu, Japan) that had been sterilized twice by circulation of hot alkaline water for $20 \mathrm{~min}$ at $75^{\circ} \mathrm{C}$ heated by bubbling with steam and then cooled with sterilized DW to around room temperature. Portions of the milk substitute (20 or 40 $\mathrm{ml}$ ) were then poured into $50-\mathrm{ml}$ sterilized polypropylene bottles and stored at $-40^{\circ} \mathrm{C}$. If necessary, bottles containing milk substitute were gamma-irradiated (30 kGy) and stored at $-40^{\circ} \mathrm{C}$ until use.

The osmotic pressure and $\mathrm{pH}$ of the formula were
$327 \mathrm{mOsm}$ and 6.51, respectively. No enterobacteria were detected in the milk.

\section{Growth rates of ICR mice fed the milk substitute}

The volume of milk substitute fed to the pups was changed daily according to their weight gain relative to the MR pups, and was increased from $0.6 \mathrm{ml}$ on day 8 to $1.2 \mathrm{ml}$ on day 15 (Fig. 1b). As shown by the growth curve in Fig. 1, the body weight of the artificially reared pups decreased on the day following the gastrostomy but increased thereafter. On day 16, the body weight of the AR pups matched that of their MR counterparts. Thirty-six AR pups survived to day 16 and 8 died during the artificial rearing from 8 to 16 days of age.

\section{Discussion}

This is the first report of a preparation of a chemically derived milk substitute for mouse pups which was devised to obtain good growth (Fig. 1).

As shown in Table 1, the average concentration of the protein in the milk of ICR, BALB/c and FVB/N mice $(11.3 \%)$ was the same as that in the SD rat $(10.5 \%)$ [5]; however, the average concentration of total fat was about two times higher (21.3\%) than that in the SD rat milk $(11.4 \%)$ [5]. With regard to the concentration of minerals, in ICR mice milk, sodium was 2.3 times lower, whereas potassium was 1.3 times higher than in rat's milk. On the other hand, the amounts of calcium and magnesium were almost identical to those found in rat's milk.

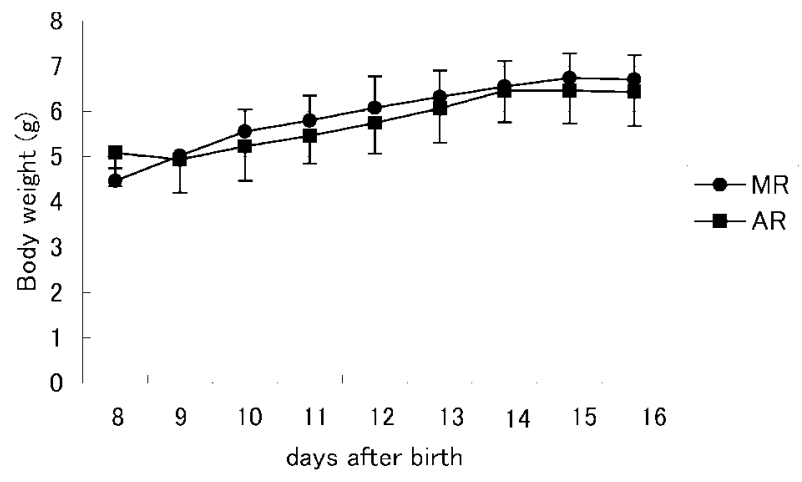

Fig 1. Weight gain of the artificially reared mice (AR: $n=36)$ and maternally reared (MR: $n=10)$ mice. AR mice were cannulated at 8 days after birth, and were artificially reared using the chemically derived milk substitute. 
The concentrations of vitamins used in the mouse milk substitute were those reported by Auested et al. [1] as they were not analyzed in this study.

AR pups grew at almost the same growth rate as MR pups, and were successfully weaned and survived for a further 7 months until the animals were sacrificed (data not shown). However, we think that it will be necessary to determine the concentration of sugar in mouse milks to make a more fitting milk substitute.

We could not artificially rear pups younger than 7 days old, because the rim of the cannula was too big to insert through the esophagus in younger pups, the tube connecting the rim being the minimum diameter that could be commercially obtained. Therefore, if pups need to be examined immediately after birth, another method, such as that developed by Hoshiba [4], would be appropriate. In addition, some modification to the composition of the formula may be required for good digestion in newborn pups. It may be possible to substitute part of the casein content with whey protein hydrolyzate.

In summary, a chemically derived milk substitute compatible with mouse milk for artificially rearing mice pups was developed. This substitute will be useful not only for the artificial rearing of mice but also for identifying dietary components contributing to metabolic influence during the suckling period.

\section{Acknowledgments}

The authors wish to thank Ms. Kyoko Koizumi, Ms. Kumiko Yamazaki of our laboratory, for their skilful technical assistance. The authors thank Ms. Makiko
Nakayama of our laboratory for useful discussions in the development of the new substitute.

\section{References}

1. Auestad, N., Korsak, R.A., Bergstrom, J.D., and Edmond, J. 1989. Milk-substitutes comparable to rat's milk: their preparation, composition and impact on development and metabolism in the artificially reared rat. Br. J. Nutr. 61: 495-518.

2. Beierle, E., Joseph, C., Hartwich, E., Iyengar, M., Wei, D., Nan, L., Demarco, V., and Neu, J. 2004. Artificial rearing of mouse pups: Development of a mouse pup in a cup model. Pediatr. Res. 56: 250-255.

3. Hall, W.G. 1975. Weaning and growth of artificially reared rats. Science 190: 1313-1315.

4. Hoshiba, J. 2004. Method for hand-feeding mouse pups with nursing bottles. Contmp. Top. Lab. Anim. Sci. 43: 5053.

5. Kanno, T., Koyanagi, N., Katoku, Y., Yonekubo, A., Yajima, T., Kuwata, T., Kitagawa, H., and Harada, E. 1997. Simplified preparation of a refined milk formula comparable to rat's milk: Influence of the formula on development of the gut and brain in artificially reared rat pups. J. Ped. Gastroenterol. Nutr. 24: 242-252.

6. Nakayama, M., Yajima, M., Hatano, S., Yajima, T., and Kuwata, T. 2003. Intestinal adherent bacteria and bacterial translocation in breast-fed and formula-fed rats in relation to suspectibility to infection. Pediatr. Res. 54: 364-371.

7. Yajima, M., Nakayama, M., Hatano, S., Yamazaki, K., Aoyama, Y., Yajima, T., and Kuwata, T. 2001. Bacterial translocation in neonatal rats: the relation between intestinal flora, translocated bacteria, and influence of milk. J. Ped. Gastroenterol. Nutr. 33: 592-601. 